Original Research Paper

\title{
Pengenalan E-Archiving System Sebagai Implikasi Korespondensi Elektronik Pada Masa Pandemi di Kecamatan Sukamulia Kabupaten Lombok Timur
}

\author{
Baharuddin, Lalu Ali Wardana, Sribagus, Kurniawan Apgrianto, Agus Saputra \\ 1. Universitas Mataram
}

https://doi.org/10.29303/jpmpi.v3i2.1191

Sitasi: Baharuddin., Wardana, L. A., Sribagus., Apgrianto, K \& Saputra, A. (2021). Pengenalan E-Archiving System Sebagai Implikasi Korespondensi Elektronik Pada Masa Pandemi di Kecamatan Sukamulia Kabupaten Lombok Timur. Jurnal Pengabdian Magister Pendidikan IPA, 4(3)

\section{Article history}

Received: 1 Oktober 2921

Revised: 30 Oktober 2021

Accepted: 20 November 2021

*Corresponding Author:

Baharuddin, Universitas

Mataram, Mataram, Indonesia

Email: bahar@unram.ac.id

\section{Pendahuluan}

Setelah Undang-undang nomor 6 tahun 2014 tentang desa disahkan, pemerintah memberikan porsi keuangan yang cukup besar untuk setiap desa. Jumlah yang dialokasikan untuk anggaran desa terus meningkat dari tahun ke tahun. Padah tahun 2015 pemerintah menganggarkan Rp 20,76 triliun, tahun 2016 sebesar Rp 46,98 triliun, tahun 2017 sebesar Rp. 60 triliun, tahun 2018 sebesar Rp 60 triliun dan tahun 2019 sebesar 73 triliun (kemenkeu, 2018). Hal ini bertujuan untuk melakukan pembanguan secara lebih merata sehingga ketimpangan pembangunan di kota dan desa tidak terlalu tinggi.

Penerapan Undang-Undang desa tersebut di atas tidak serta merta diikuti oleh upaya peningkatan kapasitas perangkat desa dalam menjalankan fungsi sebagai pengelola keuangan dan pengadministrasi kegiatan pemerintahan. Sehingga penerapan undang-undang itu oleh beberapa pihak sering disebut terlalu terburu buru dan mengagetkan. Bagaimana mungkin perangkat desa yang secara kualifikasi pendidikan rata-rata tamatan SMA dan biasanya mengurus hal -hal sederhana harus dihadapkan pada sistem administrasi yang membutuhkan kecapakan tinggi tanpa melalui proses pelatihan dan pembimbingan? Sementara administrasi yang termasuk didalamnya adalah mengarsip secara elektronik adalah seni yang tidak hanya butuh praktik tetapi juga butuh pembimbingan (Permadi 2019).

Dalam proses pelaksanaannya, masalah administrasi mulai bermunculan. Saban hari kepala desa dan perangkatnya diberitakan bermasalah secara hukum. Tidak jarang bahkan permasalahan yang muncul tersebut berujung pada pemenjaraan beberapa perangkat desa karena telah dinyatakan gagal dalam mengelola uang negara serta lalai mengadministrasikan kegiatan yang dilaksanakan. Kasus -kasus tersebut terjadi hampir di seluruh wilayah Indonesia termasuk di Nusa Tenggara Barat.

Salah satu kemampuan yang penting dimiliki oleh perangkat desa sebagai penyelenggara pemerintahan adalah kemampuan dalam melakukan mengarsip secara elektronik . Misalnya, Negosiasi atau kebijakan yang tidak diadministrasikan dalam bentuk surat menyurat biasanya tidak memiliki posisi hukum yang kuat. Bahkan suatu transaksi atau aktifitas tidak diakui secara sah apabila tidak 
didokumentasikan dengan baik yang salah satunya dapat dilihat dari proses surat menyurat (mengarsip secara elektronik)(Gallaway and Starkey 2013; Oktavia Setya Ningrum and Puspasari 2015; Vongurai 2019). Walaupun sebenarnya perangkat desa sangat terbiasa membuat surat yang berkaitan dengan kepentingan warga seperti surat jual beli tanah, surat waris, surat keterangan domisili dll, tetap saja kita masih temukan permasalahan dalam surat -surat tersebut. Apalagi sekarang mereka dituntut untuk merespon permasalahan permasalahan yang lebih kompleks.

Kesalahan dalam penulisan berbagai surat masih banyak kita temukan di masyarakat (Bansal 2020). Jenis kesalahan biasanya berupa susunan kalimat yang tidak lengkap, berbelit belit, tanda baca tidak benar, tata bahasa tidak teratur, dan salah mengadopsi bentuk dan model surat. Kesalahan tersebut dapat disebabkan oleh beberapa hal, diantaranya:

Tidak ada pengarahan dan pengendalian mengenai cara menulis surat yang baik pada suatu institusi/organisasi

Masyarakat bersifat permisif terhadap kesalahan-kesalahan dalam menulis surat sehingga tidak memicu sikap hati-hati dari penulisnya.

Mengarsip secara elektronik yang dilakukan dalam suatu kantor secara umum dapat dibagi menjadi dua;

Mengarsip secara elektronik eksternal yaitu surat menyurat yang dilakukan oleh kantor atau bagian-bagiannya kepada pihak luar. Misalnya, surat yang ditulis oleh kepala desa kepada camat atau pemerintah kabupaten.

Mengarsip secara elektronik Internal yaitu surat menyurat yang dilakukan oleh individu atau bagian dalam sebuah kantor atau lingkungan kerja. Hal ini penting dilakukan untuk mempertegas fungsi dan tanggung jawab individu atau bagian dalam sebuah institusi. Misalnya, surat tugas yang dikeluarkan oleh kepala desa kepada perangkat desa untuk melakukan fungsi tertentu.

Mengingat pentingnya kemampuan mengarsip secara elektronik serta mencermati permasalahan yang sering muncul pada masyarakat, Jurusan Pendidikan Bahasa dan Seni FKIP Universitas Mataram dalam mejalankan fungsi tridarma perguruan tinggi bermaksud untuk mengeliminasi permasalahan tersebut melaui pemberian pelatihan mengarsip secara elektronik bertema 'Pengenalan Sistem El-Archives Untuk
Meningkatkan Kapasitas Perangkat Desa Di Kecamatan Sukamulia Kabupaten Lombok Timur'. Kegiatan ini dimaksudkan melatih kemampuan perangkat desa dalam memahami pentingnya fungsi surat, mengidentifikasi jenis-jenis surat, menulis surat dengan format serta bahasa yang baik.

\section{Metode}

Pelatihan ini akan di laksanakan di desa Padamara dan melibatkan perangkat desa dari seluruh desa yang terdapat di kecamatan Sukamulia Kabupaten Lombok Timur. Secara umum, kegiatan pelatihan ini akan meliputi:

Ceramah , yaitu pemberian konsepkonsep dasar mengarsip secara elektronik secara pemberian contoh surat yang telah sesuai dengan konsep tersebut.

Pembimbingan, yaitu peraktek penulisan surat yang dilakukan oleh masing -masing perangkat desa secara terbimbing. Dalam hal ini, tim pengabdian akan memulai dengan penyusunan surat berdasarkan kasus yang sering dihadapi oleh perangkat desa sebagai pelayan masayarakat.

Ceramah akan dilaksanakan secara offline dengan mengikuti protokol kesehatan bila memungkinkan. Bila dalam keadaan yang tidak memungkinkan untuk dilaksanakn oflline, maka akan dilaksankan online dengan bantuan dan fasilitas kantor desa/lokal setempat untuk menyediakan ruangan tempat peserta berkumpul dengan tambahan fasilitas layar besar untuk memudahkan ceramah. Dalam pembimbingan/pendampingan beberapa mahasiwa yang berasal dari daerah setempat dapat dilibatkan untuk memberikan penjelasan yang lebih rinci mengenai pengarsipan secara elektronik.

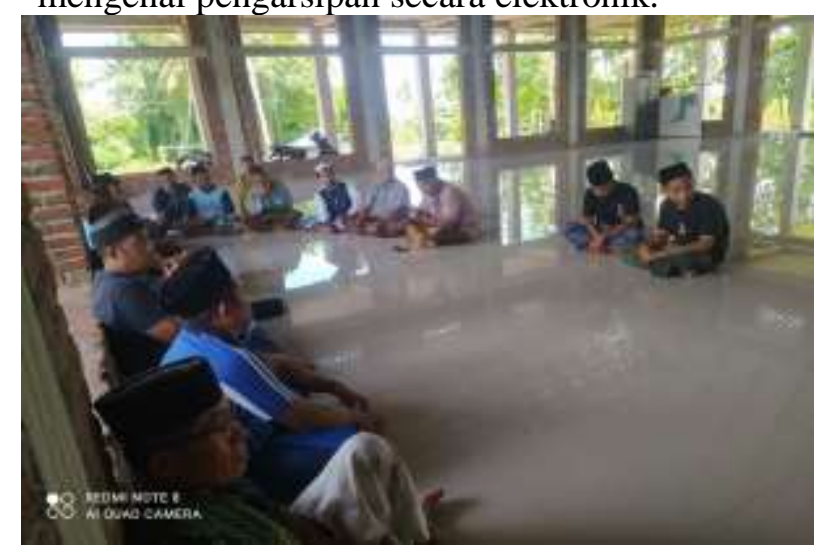




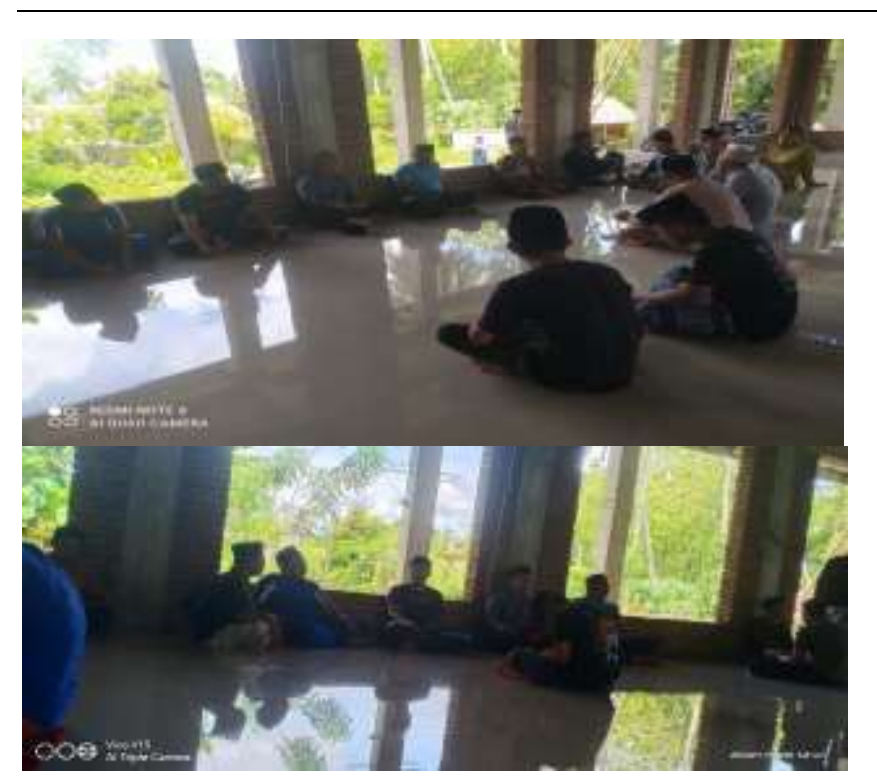

Pengarsipan secara online yang memanfaatkan google drive kemudian disingronkan dengan moden 1 pengarsipan offline pada komputer dengan memanfaatkan satu drive fixed yang ada pada komputer atau menggunakan drive luar seperti portable hard disk yang dapat dipindahkan dan diakses pada komputer lain secara bebas dalam arti tamnpa hambatan dalam mengaksesnya.

\section{Hasil dan Pembahasan}

\section{Cara Menggunakan Google Drive}

Cara menggunakan Google Drive sebaiknya perlu Anda ketahui. Sebab, kini berbagai data penting haruslah dicadangkan agar terjamin keamanan serta kualitasnya. Seperti yang diketahui, kini berbagai data pun selalu dibuat dan disimpan dalam bentuk digital bukan lagi dengan cara yang konvensional.

Suatu saat, berbagai dokumen penting yang telah dibuat tersebut pasti akan dibutuhkan kembali. Namun, menyimpan banyak dokumen di gawai Anda pun sebenarnya juga tidak cukup aman dan terlindungi. pencadangan dokumen dibutuhkan yang lebih terjamin. Salah satunya yaitu dengan memanfaatkan fitur dari Google.

Seiring berjalannya waktu, kini Google Drive pun hadir dengan tingkat keamanan dan kapasitas yang selalu ditingkatkan. Hal ini tidak lain untuk memberikan kenyamanan dan keamanan bagi para pengguna. Berbagai cara menggunakan Google
Drive pun kini dapat dilakukan dengan mudah seperti mengunggah hingga membagikan dokumen Anda. Simak penjelasan selengkapnya mengenai cara menggunakan Google drive yang berhasil dirangkum dari berbagai sumber yang didapatkan di internet. Untuk mendapatkan berbagai manfaatnya tersebut, hal pertama yang harus diketahui adalah dengan memahami cara menggunakan Google Drive. Pengguna tidak akan dapat memperoleh akses apabila tidak memiliki akun Google terlebih dahulu.

\section{E-Archieving}

Pengarsiana adalah hal yangasangat penting (Hakim 2015; Muhammad and Anwary 2019). Cara menggunakan Google Drive sebaiknya perlu Anda ketahui. Sebab, kini berbagai data penting haruslah dicadangkan agar terjamin keamanan serta kualitasnya. Seperti yang diketahui, kini berbagai data pun selalu dibuat dan disimpan dalam bentuk digital bukan lagi dengan cara yang konvensional.

Suatu saat, berbagai dokumen penting yang telah dibuat tersebut pasti akan dibutuhkan kembali. Namun, menyimpan banyak dokumen di gawai Anda pun sebenarnya juga tidak cukup aman dan terlindungi. Anda membutuhkan pencadangan dokumen yang lebih terjamin. Salah satunya yaitu dengan memanfaatkan fitur dari Google.

Seiring berjalannya waktu, kini Google Drive pun hadir dengan tingkat keamanan dan kapasitas yang selalu ditingkatkan. Hal ini tidak lain untuk memberikan kenyamanan dan keamanan bagi para pengguna. Berbagai cara menggunakan Google Drive pun kini dapat dilakukan dengan mudah seperti mengunggah hingga membagikan dokumen Anda.

\section{Kesimpulan}

Implementasi aplikasi e-archieve di Desa Padamara Lombok Timurini sudah disesuaikan dengan SOP yang dibuat agar pengarsipan lebih efektif dan berdaya guna, maka dari itu implementasi aplikasi e-archieve tentang pengelolaan surat aktif sudah tidak ada kendala. Desa Padamara Lombok Timur didukung dengan penggunaan perangkat sistem kearsipan elektronik yaitu hardware dan software. Hardware yang digunakan yaitu seperangkat komputer, printer, scanner. Sedangkan software yang digunakan yaitu 
sebuah aplikasi berbasiskan website dengan jaringan internet dengan memanfaatkan Gogle Drive sebagai tempat penyimpanan online untuk earchieve.

\section{Daftar Pustaka}

Bansal, Arvind Kumar. 2020. - Syntax and Semantics. Vol. 14.

Gallaway, Teri Oaks and Jennifer Starkey. 2013. "Google Drive." The Charleston Advisor 14(3).

Hakim, Triono Dul. 2015. "PENGELOLAAN ARSIP DI ERA TEKNOLOGI INFORMASI." Jurnal Ilmu Budaya 11(2).

Hebrasianto Permadi, Dimas Fanny. 2019. "DEVELOPING INFORMATION SYSTEM OF MANAGEMENT ARCHIEVING CORRESPONDING MAIL BASED ON WEBSITE." JOSAR (Journal of Students Academic Research) 4(1).

Muhammad, Rom Ubaidillah and Ahdie Anwary. 2019. "Archieve Media Promotion for Collective Memory Safety on Digital Natives Generations." Record and Library Journal 5(1).

Oktavia Setya Ningrum and Durinta Puspasari. 2015. "Penggunaan Aplikasi Google Drive Sebagai Penunjang Paperless Office." Ilmu Sosial.

Vongurai, Rawin. 2019. "Factors Affecting Net Benefit of Google Drive Adoption Decision: A Case Study of Thais' Living in Bangkok, Thailand." International Journal of Economics and Business Administration 7(4). 